\title{
Adsorption of Fe Ions from Aqueous Solution Using $\alpha$-Keratin-Coated Alginate Biosorbent
}

\author{
G. Fadillah, E. N. K. Putri, S. Febrianastuti, E. V. Maylinda, and C. Purnawan
}

\begin{abstract}
The biosorbent $\alpha$-keratin-alginate (KA) was prepared by using the encapsulation technique in $\mathrm{CaCl}_{2} 2 \%$ (w/v) solution. The biosorbent was characterized by Fourier Transform Infrared (FTIR) and Scanning Electron Microscope (SEM). The extent of adsorption was found to be a function of the composition of $\alpha$-keratin and alginate, the $\mathrm{pH}$ of solution and contact time. The optimum adsorption of $\mathrm{Fe}$ ions in aqueous solution was found at the composition of $\alpha$-keratin and alginate of $1: 2(w / w)$, the $\mathrm{pH}$ at 7.0 and contact time at 60 minutes. The adsorption of $\mathrm{Fe}$ ions on $\mathrm{KA}$ biosorbent was comparatively higher than $\alpha$-keratin and alginate only. The adsorption capacity of $\mathrm{KA}$ biosorbent has the maximum adsorption capacity of $658.4 \mathrm{mg} / \mathrm{g}$ while biosorbent $\alpha$-keratin and alginate are $464.7 \mathrm{mg} / \mathrm{g}$ and $528.1 \mathrm{mg} / \mathrm{g}$, respectively. Adsorption of $\mathrm{Fe}$ ions in aqueous solution followed the Freundlich adsorption isotherm, and the dynamic adsorption model could be described through a pseudo-second order kinetics.
\end{abstract}

Index Terms - a-keratin, adsorption, alginate, biosorbent, Fe.

\section{INTRODUCTION}

The growth of industrial such as mining, petroleum, and electroplating can produce containing heavy metals which are toxic to the environment [1]. The presence of heavy metals such as $\mathrm{Fe}$ ions in water can potentially to effects on the environment and human life. World Health Organization (WHO) in 1996 had recommended maximum level (MCL) of $\mathrm{Fe}$ in water as $0.3 \mathrm{mg} / \mathrm{litre}$. Fe levels in water vary depending on several factors and it can be dissolved in the water or so heavy that it forms a precipitate or microscopic solid pieces suspended in water. At higher levels, the Fe ions can build up in animals internal organ, eventually killing them and sometimes can increase acidity of water so it can kill or hurt the aquatic of life. In addition, the higher level of $\mathrm{Fe}$ ions can effect to health, which can lead to liver, heart and pancreatic damage [2]. Interestingly, the removal of $\mathrm{Fe}$ ions from water is an urgent requirement for providing a good health. Many common methodologies such as adsorption, precipitation, membrane filtration and ion exchange have been widely employed for $\mathrm{Fe}$ ions uptake from wastewater. The removal of $\mathrm{Fe}$ ions by the adsorption technique appeared to be an

Manuscript received November 9, 2017; revised December 9, 2017. This work was supported RISTEKDIKTI (Ministry of Research, Technology and Higher Education of the Republic of Indonesia), LPDP (Indonesian Endowment Fund for Education).

G. Fadillah is with Institute of Technology Bandung, Indonesia (e-mail: ganjarfadillah@students.itb.ac.id, ganjarfadillah52@gmail.com).

E. N. K. Putri, S. Febrianastuti, E. V. Maylinda, and C. Purnawan are with Sebelas Maret University, Indonesia (email: elsaninsa22@gmail.com, syahnafebri97@gmail.com, candra_pr@gmail.com). efficient, economical, simple and used for numerous years [3].

The currently research on adsorbents is using a lot of materials based on organic materials with the principle of waste for waste such as $\alpha$-keratin. The $\alpha$-keratin sources are as numerous as in chicken feathers and human hair, even the main chemical content of the hair is $88-96 \% \alpha$-keratin protein [4]. This shows that $\alpha$-keratin has the potential to be further developed. $\alpha$-keratin is capable of acting as an adsorbent because it has a binding amino and hydroxyl functional group which causes the cation polyelectrolyte properties to act as ion exchangers and potentially developed as adsorbents such as for removal of $\mathrm{Fe}$ ions [5].

The material that can be developed as a composite is alginate. This is given that the source of alginate in Indonesia so much and it is currently getting the limelight related to the potential of alginate as an adsorbent material. Alginate can protect $\alpha$-keratin from environmental damage and impact so that the physical endurance of the adsorbent material can be increased. Alginate with $\alpha$-keratin will have cross-reactions in the group which results in the formation of amide bonds between carboxylates and amines so that their physical strength becomes better [6]. In the current study, biosorbent was synthesized and used to develop new series of calcium alginate encapsulated $\alpha$-keratin to increase the adsorption capacity and physical properties. The developed materials biosorbent were investigated as potential biosorbent for efficient removal of $\mathrm{Fe}$ ions from water.

\section{MAtERIALS AND MethodS}

\section{A. Materials}

The biosorbent used is composed of $\alpha$-keratin encapsulated by calcium alginate. Sodium alginate, calcium chloride anhydrous $\geq 93 \%$, ferric chloride $97 \%$, nitric acid $70 \%$, sodium hydroxide were supplied by Sigma-Aldrich (Singapore). The hair as a source of $\alpha$-keratin from Surakarta, Indonesia was used. All chemicals were analytical graded.

\section{B. Preparation of $\alpha$-Keratin Powder, Biosorbent KA and Characterization}

The hair was washed with detergent in several times and dried in the sun to dry. Then, the hair was milled to fine at 180 mesh. The obtained hair powder was washed with acetone for 30 minutes and filtered through whatman filter paper. Then the residue was dried with an oven at $40{ }^{\circ} \mathrm{C}$ for 30 minutes. Cleaned hair powder and technical alginate were weighed with the variations of $\alpha$-keratin:alginate weight composition are 1:1, 1:2, 1:3,2:1, and 3:1. Then a mixture of hair and alginate with some composition, dissolved with 
aquadest of $50 \mathrm{~mL}$. The obtained $\alpha$-keratin-alginate solution, encapsulated with $\mathrm{CaCl}_{2} 2 \%$ (w/v) solution immersed in ice cubes. The result of the encapsulation of $\alpha$-keratin-alginate (KA) composite was filtered and dried at $60{ }^{\circ} \mathrm{C}$ for 8 hours. Then, the optimal composition was carried out by adsorption test on Fe ions in aqueous solution at the optimum condition of $\mathrm{pH}$ (7.0) and contact time (60 minutes). The biosorbent was characterized using FTIR spectra and SEM micrograph. FTIR spectra of biosorbent were recorded in a Perkin-Elmer-238B FTIR spectrophotometer over the wave range $4000-400 \mathrm{~cm}^{-1}$. SEM photographs were taken with JSM 6700F Scanning Microscope to examine the morphology of biosorbent.

\section{Equilibrium Adsorption and Kinetics Study Adsorption Isotherm}

Fe ions solution with various designated concentrations and optimum $\mathrm{pH}$ (7.0) was prepared. The biosorbent KA (100 mg) was added into the Fe ions solutions. During the experiments, the mixtures were shaken on a shaker with stirred speed of $200 \mathrm{rpm}$ for 60 minutes. The metal concentrations of final solutions (after 60 minutes stirring) were analyzed by Atomic Absorption Spectrophotometry (AAS). All experiment was carried out at $298 \mathrm{~K}$.

Adsorption kinetics, the biosorbent KA (100 mg) was added into the Fe ions solutions while being stirred with a speed of $200 \mathrm{rpm}$ and optimum pH (7.0) at $298 \mathrm{~K}$. The sample solutions were taken at various of time intervals and the concentrations of the metal ions were measured by AAS. The common mathematical model used to describe adsorption kinetics absorption kinetics included the Lagergen's pseudo-first-order and pseudo-second-order.

\section{RESUlTS AND DisCUSSIONS}

\section{A. Shynthesis and Characterization}

The synthesis of KA biosorbent was carried out by encapsulation method. Encapsulation method is carried out in $\mathrm{CaCl}_{2}$ solution which serves as a crosslinking agent to form a $\alpha$-keratin-alginate composite. The principle of encapsulation is the exchange of $\mathrm{Na}^{+}$ions from Na-alginate with $\mathrm{Ca}^{2+}$ from $\mathrm{CaCl}_{2}$ when dropped into $2 \% \mathrm{CaCl}_{2}$ solution, forming a $\mathrm{Ca}$-alginate gel. The illustration of synthesis biosorbent is shown in Fig. 1.

The FTIR spectra of KA, alginate, and $\alpha$ are shown in Fig. 2(a). The specific spectrum of $\alpha$-keratin-alginate (KA) biosorbent shows absorption bands at $3423 \mathrm{~cm}^{-1}(\mathrm{OH}$ stretching), $1639 \mathrm{~cm}^{-1}$ (COO- symmetric stretching). In addition, there is a characteristic absorption of peptide bonds (-CONH-) with three absorption areas which is Amide I, Amide II, and Amide III. The absorption area of Amide I shows the absorption of $\mathrm{C}=\mathrm{O}$ stretching vibrations at wave numbers 1600 and $1622 \mathrm{~cm}^{-1}$, Amide area II shows the absorption of $\mathrm{C}-\mathrm{N}$ stretching and $\mathrm{N}-\mathrm{H}$ bending vibrations at wave numbers 1450 and $1420 \mathrm{~cm}^{-1}$. Meanwhile, the amide III

region indicates the absorption of $\mathrm{N}-\mathrm{H}$ bending, $\mathrm{C}-\mathrm{N}$ stretching on $\mathrm{O}=\mathrm{C}-\mathrm{N}$ bonds with wave numbers 1367and $1300 \mathrm{~cm}^{-1}$. In keratin and $\alpha$-keratin-alginate composites, there is also a disulfide group absorption (S-S) in the wave number 1074 and $1038 \mathrm{~cm}^{-1}$. The specific of absorption wavenumber proves that the $\alpha$-keratin-alginate composite has been formed. The SEM morphology of KA (Fig. 2(b)) shows that alginate is attached to the $\alpha$-keratin surface. This proves that $\alpha$-keratin has been protected by an alginate matrix so that $\alpha$-keratin has a stronger physical resistance to environmental damage and impact on the adsorption process of Fe ions.

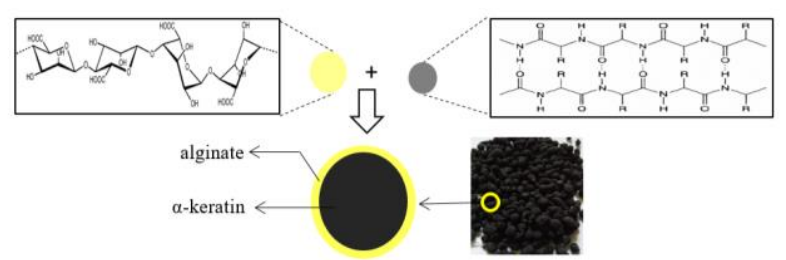

Fig. 1. Illustration of synthesis of KA biosorbent.

\section{A. Influemce of Composition Biosorbent, $\mathrm{pH}$ and Contact Time}

The composition between $\alpha$-keratin and alginate needs to be studied because it will affect the density of the resulting composite. The results of composition testing are shown in Table I. The composition of $\alpha$-keratin and alginate (1:2) was found optimum results.

In addition, the comparison of composition biosorbent, the other parameters influencing the adsorption capacity are the $\mathrm{pH}$ of solution and contact time. The result of the influence of $\mathrm{pH}$ and contact time to adsorption Fe ions are shown in Fig. 3. The influence of $\mathrm{pH}$ was not studied beyond 9.0 due to the formation of a precipitate. The optimum $\mathrm{pH}$ for $\mathrm{KA}$ biosorbent was found to be 7.0 with the maximum contact time at 60 minutes for $\mathrm{Fe}$ ions adsorption. The effect of $\mathrm{pH}$ on adsorption capacity may be discussed on the basis of the nature of the chemical interactions of $\mathrm{Fe}$ ions with the biosorbent. The carboxylic $(-\mathrm{COOH})$ from alginate and amino $\left(-\mathrm{NH}_{2}\right)$ groups present from $\alpha$-keratin on the biosorbent are responsible for the binding of Fe ions [7]. At lower $\mathrm{pH}$, the carboxylic groups retain their protons and amino groups get protonated, thereby, reducing the probability of binding to any positively charged ions.
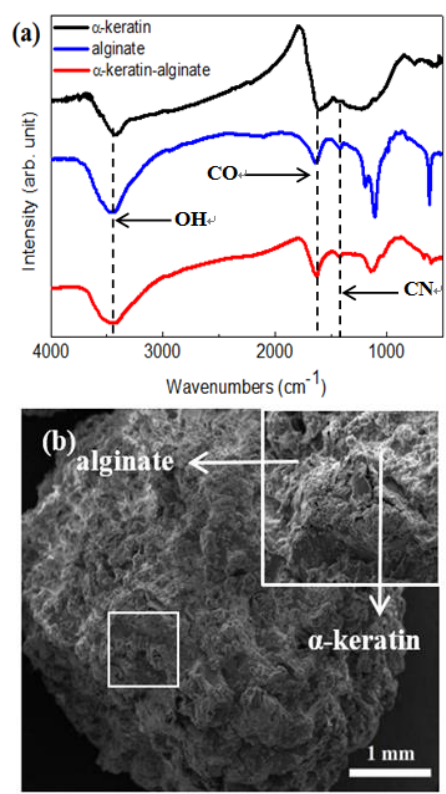

Fig. 2. (a) FTIR characterization of $\alpha$-keratin, alginate and KA; (b) SEM characterization of KA biosorbent. 
TABLE I: INFLUENCE OF COMPOSITION KA BIOSORBENTS TO ADSORPION FE IONS

\begin{tabular}{ccc}
\hline $\begin{array}{c}\boldsymbol{\alpha} \text {-keratin : } \\
\text { alginate }\end{array}$ & $\begin{array}{c}\text { mass of biosorbent } \\
(\mathbf{m g})\end{array}$ & $\begin{array}{c}\text { adsorption capacity } \\
(\mathbf{m g} / \mathbf{g})\end{array}$ \\
\hline $1: 1$ & & 140.81 \\
$1: 2$ & & 205.64 \\
$1: 3$ & 100 & 103.96 \\
$2: 1$ & & 158.52 \\
$3: 1$ & & 6.16 \\
\hline
\end{tabular}

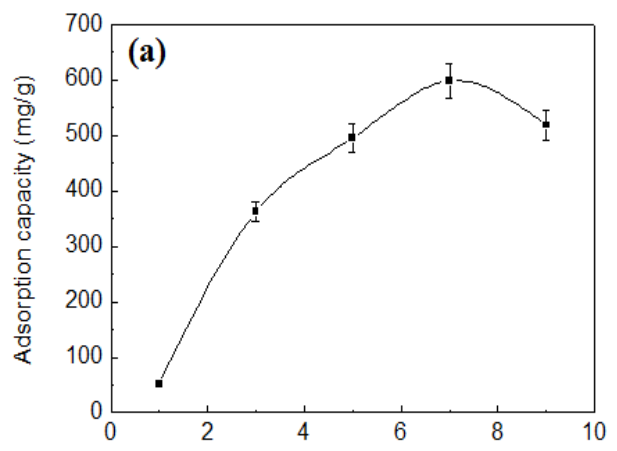

$\mathrm{pH}$

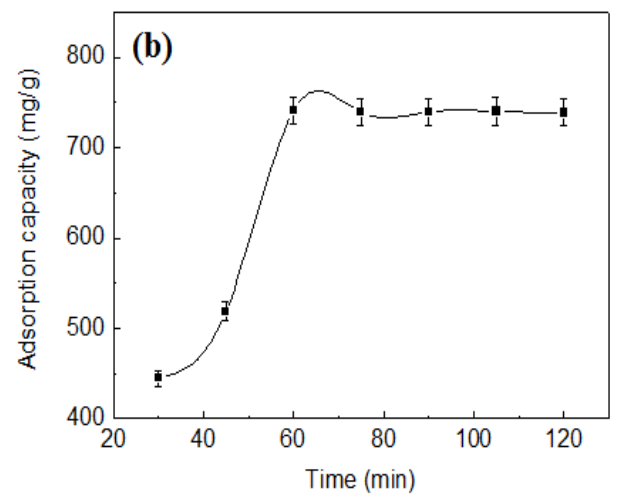

Fig. 3. (a) Influence of $\mathrm{pH}$ solution and (b) contact time to adsorption of $\mathrm{Fe}$ ions.

In addition, at lower $\mathrm{pH}$, this is mostly due to the competition of $\mathrm{H}^{+}$ion adsorption with metal ions so it caused the adsoprtion capacity at low $\mathrm{pH}$ is relatively small [8]. While, at the $\mathrm{pH}$ more than 8 case the precipitation of iron hydroxide, $\mathrm{Fe}(\mathrm{OH})_{3(\mathrm{~s})}[9],[10]$. In this study, at the $\mathrm{pH} \leq 7$, the hydrolysis does not occur. Some of the literatur said that the hydrolysis of ferric ions is aqueous solutions is a complicated time and concentration-dependent system [10].

The batch studied show that the KA biosorbent has the biggest adsorption capacity of $658.4 \mathrm{mg} / \mathrm{g}$ while biosorbent $\alpha$-keratin and alginate are $464.7 \mathrm{mg} / \mathrm{g}$ and $528.1 \mathrm{mg} / \mathrm{g}$, respectively. This occurs because in KA biosorbent the presence of $-\mathrm{COO}^{-}$and $-\mathrm{NH}_{2}$ groups can increase the absorption of larger amounts of $\mathrm{Fe}$ ions.

TABLE II: LANGMUIR AND FREUNDLICH ISOTHERM CONSTANTS FOR ADSORPTION OF FE IONS ON KA

\begin{tabular}{|c|c|c|c|c|c|c|}
\hline \multicolumn{3}{|c|}{ Langmuir } & \multicolumn{3}{|c|}{ Freundlich } & \multirow[b]{2}{*}{$\mathrm{q}_{\mathrm{e}}(\mathrm{mg} / \mathrm{g})$} \\
\hline $\begin{array}{c}\mathrm{q}_{\mathrm{m}} \\
(\mathrm{mg} / \mathrm{g})\end{array}$ & $\begin{array}{c}\mathrm{K}_{\mathrm{L}} \\
(\mathrm{L} / \mathrm{mg})\end{array}$ & $\mathrm{R}^{2}$ & $\begin{array}{c}\mathrm{K}_{\mathrm{F}} \\
(\mathrm{L} / \mathrm{mg})\end{array}$ & $\mathrm{n}$ & $\mathrm{R}^{2}$ & \\
\hline 2876 & 1,08 & 0,93 & 1612 & 1,45 & 0,99 & 1108 \\
\hline
\end{tabular}

\section{B. Adsorption Isotherms and Adsorption Kinetics}

For the adsorption isotherms study, the Freundlich and Langmuir isotherms were used to fit the experimental data. The results from adsorption isotherms study are given in
Table II. From the experimental results showed that the adsorption process of $\mathrm{Fe}$ ions by KA biosrobent follows Freundlich isotherm. This is because the value of $\mathrm{R}^{2}$ obtained is greater than Langmuir isotherm and the value of $\mathrm{q}_{\mathrm{e}}$ calculated near the $\mathrm{q}_{\mathrm{e}}$ experiment. The Freundlich isotherm is an empirical equation based on an exponential distribution of sorption sites and energies and the results of $\mathrm{K}_{\mathrm{F}}$ is an indicator adsorption capacity of biosorbent.

The reaction kinetics model which studied in this research is the pseudo-first order and pseudo-second order kinetics model. The model of adsorption kinetics is given in Table III. From the calculation results show that the adsorption of $\mathrm{Fe}$ ions follows the pseudo-second order. The second order kinetic model assumes that the rate-limiting step may be chemical adsorption [11], [12].

TABLE III: PSEUdO-FIRST ORDER AND SECOND ORDER RATE CONSTANTS FOR ADSORPTION OF FE IONS ON KA

\begin{tabular}{|c|c|c|c|c|c|c|}
\hline \multicolumn{3}{|c|}{ Pseudo-first order } & \multicolumn{3}{|c|}{ Pseudo-second order } & \multirow[b]{2}{*}{$\begin{array}{c}\mathrm{q}_{\mathrm{e}} \\
\text { experiment } \\
(\mathrm{mg} / \mathrm{g})\end{array}$} \\
\hline $\begin{array}{c}\mathrm{q}_{\mathrm{e}} \\
(\mathrm{mg} / \mathrm{g})\end{array}$ & $\begin{array}{c}\mathrm{k}_{1} \\
\left(\min ^{-1}\right)\end{array}$ & $\mathrm{R}^{2}$ & $\begin{array}{c}\mathrm{q}_{\mathrm{e}} \\
(\mathrm{mg} / \mathrm{g})\end{array}$ & $\begin{array}{c}\mathrm{k}_{2} \\
\left(\mathrm{~g} \cdot \mathrm{mg}^{-1}\right. \\
\left.\min ^{-1}\right)\end{array}$ & $\mathrm{R}^{2}$ & \\
\hline 1605 & 0,07 & 0,73 & 961 & $\begin{array}{c}3,47 \mathrm{x} \\
10^{-5}\end{array}$ & 0,95 & 741 \\
\hline
\end{tabular}

\section{CONCLUSIONS}

In this study, $\alpha$-keratin-alginate (KA) was developed as biosorbent and characterized using FTIR spectra and SEM micrograph. Adsorption of Fe ions on KA was investigated using batch systems. The data demonstrated that the biomaterials are effective adsorbents for the removal of $\mathrm{Fe}$ ions from aqueous solution. The adsorption of $\mathrm{Fe}$ ions depended on the composition of $\alpha$-keratin and alginate, $\mathrm{pH}$ of the metal solution and contact time of adsorption process. The equilibrium adsorption data were correlated well by Freundlich isotherm equations the adsorption kinetics followed pseudo-second order kinetics model. So, the biomaterial has potential to be developed as a biosorbent material of Fe ions adsorption.

\section{REFERENCES}

[1] K. V. Gupta, M. Gipta, and S. Sharma, "Process development for the removal of lead and chromium from aqueous solutions using red mud-an alumunium industri," Water Research, pp. 1125-1134, vol. 35, 2001.

[2] G. O. Oyetibo, K. Miyauchi, Y. Huang, M. F. Chien, M. Illori et al., "Biotechnological remedies for the estuarine environment polluted with heavy metals and persistent organic pollutants," International Biodeterioration \& Biodegradation, pp. 614-625, Vol. 119, 2016.

[3] B. Volesky, "Biosorption for the next century," International Proceedings of the International Biohydrometallurgy Symposium, Spain: El Escorial, 1999.

[4] A. Aluigi, C. Tonetti, C. Tonin, and G. Mazzuchetti, "Adsorption of copper(II) ions by keratin/PA6 blends nanofibers," European Polymer Journal, pp. 1756-1764, vol. 47, 2011.

[5] V. Volkov and A. C. Paulo, "Enzymatic phosphorylation of hair keratin enhances fast adsorption of cationic moieties," International Journal of Biological Macromolecules, pp. 476-486, vol. 85, 2016.

[6] R. Silva, R. Singh, B. Sarker, D. Papageorgiou et al., "Hybrid hydrogels based on keratin and alginate for tissue engineerin," Journal of Materials Chemistry B, pp. 5441-5451, vol. 2, 2014.

[7] K. S. Low, C. K. Lee, and K. K. Tan, "Biosorption of basic dyes by water hyacinth roots," Bioresource Technolology, pp. 79-83, vol. 52, 1995 . 
[8] P. L. Homagai, H. Paudyal, and K. N. Ghimire, "Adsorption kinetics of $\mathrm{Pb}(\mathrm{II}), \mathrm{Cd}(\mathrm{II}), \mathrm{Zn}$ (II) and $\mathrm{Fe}(\mathrm{III})$ onto saponified apple waste," Journal of Nepal Chemical Society, pp. 102-105, vol. 23, 2008.

[9] S. Hashemian, S. H. Hosseini, H. Salehifar, and K. Salari, "Adsorption of $\mathrm{Fe}(\mathrm{III})$ from aqueous solution by linde type-A zeolite," American Journal of Analytical Chemistry, pp. 123-126, vol. 4, 2013.

[10] A. Stefansson, "Iron(III) hydrolisis and solubility at $25{ }^{\circ} \mathrm{C}$," Environmental Science \& Technology, pp. 6117-6123, vol. 41, 2007.

[11] Y. S. Ho and G. H. McKay, "The kinetics of sorption of divalent metal ions onto sphagnum moss peat," Water Resources, pp. 735-742, vol. $34,2000$.

[12] A. O. Dada, A. P. Olalekan, A. M. Olatunya, and O. Dada, "Langmuir, Freundlich, Temkim and Dubinin-Radushkevich isotherms of equilibrium sorption of $\mathrm{Zn}^{2+}$ unto phosporic acid modified risk husk," Journal of Applied Chemistry, pp. 38-45, vol. 3, 2012

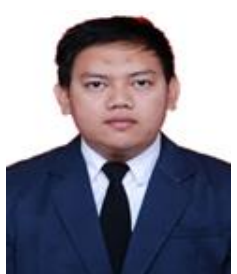

Ganjar Fadillah was born in June 1991. He graduated from Sebelas Maret University. Now, he is studying for Master degree programs at Analytical Chemistry Research Group, Faculty of Mathematics and Natural Sciences, Institute of Technology Bandung, Indonesia. His research interest are environment science such as adsorption process, photo / electrodegradation of dye waste and electrochemical for sensor and biosensor applications.

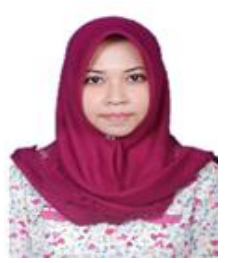

Elsa Ninda Karlinda Putri was born in March 1996 Now, she is studying for Bachelor degree programs at Analytical and Inorganic Chemistry Research Group Faculty of Mathematics and Natural Sciences, Sebelas Maret University, Indonesia. Her research interest are environment science especially in adsorption process for water.

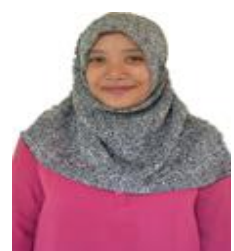

Syahna Febrianastuti was born in February 1997 Now, she is studying for Bachelor degree programs at Analytical and Inorganic Chemistry Research Group, Faculty of Mathematics and Natural Sciences, Sebelas Maret University, Indonesia. Her research interest are environment science especially in adsorption process for water.

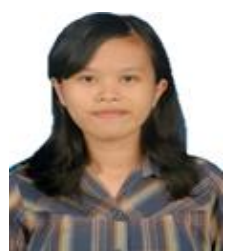

Easy Vicky Maylinda was born in May 1997. Now, she is studying for Bachelor degree programs at Analytical and Inorganic Chemistry Research Group, Faculty of Mathematics and Natural Sciences, Sebelas Maret University, Indonesia. Her research interest are environment science especially in adsorption process for water.

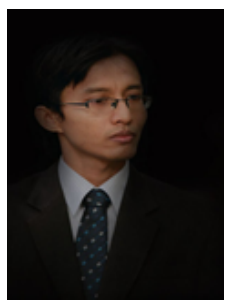

Candra Purawan was born in December 1978. He obtained the measter degree at Gadjah Mada University. He is lecturer in Dept. of Chemistry, Sebelas Maret University. He has published many article about environment field especially in adsorption process. His research interest are environment science included adsorption process, organic membrane for seperation process and fuel cell, photo/electrodegradation dyes process. 